vy inteligence je prevažující duševní činnost $v$ povolání a výše vzdèlání. Jeji sepětí se společenským systémem je realizováno změnou sociálního postavení a úsilím o myšlenkovou identifikaci s marxismem-leninismem.

Životní způsob je zakotven $v$ sociální struktuře společnosti a $\mathrm{v}$ jejím pohybu a $s$ ní podléhá procesưm integrace $i$ diferenciace. $V$ souladu s postupným vyrovnáváním sociálních a životních podminek se integruji také jednotlivé komponenty životního zpoisobu predevším ve vertikální linii a prevahy nabývá diferenciace $\mathrm{v}$ rovině horizontální a individuální. $V$ průbèhu dalšího vývoje tedy bude docházet $\mathrm{k}$ jisté individualizaci $\mathrm{v}$ životním způsobu a zároveñ $\mathrm{k}$ socializaci individuálních forem na úroveň společnosti a účasti na obecných, celospolečensky uznávaných hodnotách a aktivitách.

Zvláštními sociálními skupinami, jejichž specifiku $\mathrm{v}$ životním zposobu autoři analyzují, jsou zamèstnaní lidé, mládež, staří lidé - a také tady ukazují další perspektivy vývoje. Docházejí $\mathrm{k}$ závěru, že $\mathrm{z}$ hlediska tvorby socialistického životního způsobu je velmi dìležité věnovat prvořadou pozornest formování socialistických postojů mladé generace a racionálnímu ovlivnèní lidî $v$ tzv. postproduktivním věku.

Závěrečná část studie je věnována $v y$ braným problémům rozvoje životního způsobu, konkrétně přeměnám $v$ povaze práce, které jsou pro vývoj rozhodujicí, vývoji :kvalifikace a vzdělání spolu se společenskou angažovaností, relaci pracovní a mimopracovní doby, využití volného času, vývoji rozdèlování a sociálních jistot. Každý z těchto faktorů má svou specifiku a obsahuje další dílčí problémy. Rešit je autoři nechtějí a ani nemohou. Jejich prâce je jistou fází ve výzkumu složité a společensky závažné problematiky, kterou se tým systematicky zabývá. Bylo by proto neuvážené vytýkat, že některé ve studii obsažené prognózy jsou diskusní - ostatně to jsou svým zpơsobem všechny společenské prognózy, protože jejich pravdivost prověruje teprve čas - nebo málo argu- mentované, Prujiměme raději studii jako pracovní základ a jako mnohostranný podnèt inspirujićí $\mathrm{k}$ dalšim úvahám o budoucnosti sacialistického životního zpưsobu $\checkmark$ naší společnosti.

7itka Havlová

\section{Lebensweise und Moral im Sozialismus (Berlin 1972)}

Jednou z četných publikací NDR z poslední doby zabývajících se aktuálními otázkami životního zpusobu je kniha Životní zpưsob a morálka za socialismu (Lebensweise und Moral im Sozialismus).

Tato kolektivní monografie se zabývá problémy životního způsobu $v$ rozvinuté socialistické společnosti. V sedmi kapitolách zkoumá morálku a životní způsob $v$ období truídního boje, utvárení nového člověka v NDR, vztah osobnosti a společnosti za socialismu, odpovědnost osobnosti jako občana, vliv socialistického pracovního procesu na vývoj morálky a otázky osobního života člověka v socialistické společnosti.

Velká pozornost je věnována analýze pojmu "životní zpưsob". Tato analýza se provádí na širokém historickém pozadí. Z̈ivotní zpi̊sob zahrnuje podle názorů autorů pracovní proces ì volný čas, všechny formy životní činnosti člověka, zahrnuje prvky jak materiálního, tak i duchovního života společnosti. V životním způsobu se odrážeji obyčeje, tradice, kultura určitého národa.

Autoři publikace se zamýšlejí nad vztahem mezi životuím způsobem a způsobem myšlení a konstatují, že mezi obèma existuje složitý zprostředkovaný vztah, nebot z ekonomických vztahủ vznikají určité zájmy, objevuji se stimuly, utvár̆í se jakýsi zprostřredkovací článek, jehož prostrednictvím působí životní způsob na zpน̊sob myšlení lidí. Kniha ukazuje všechnu složitost a zprostředkovanost vztahủ mezi Životním způsobem a zpisobem myšlení lidí, autoři přecházeji $\mathrm{k}$ charakterizování socialistického životního způsobu, poukazují na reálné rozpory socialismu, hledají způsoby jefich řešení, jejich souvislost 
s procesem utváření socialistického způsobu myšlení.

Od obecného pojmu životní způsob přecházeji autoři ke specifikaci tohoto pojmu, vymezuji životní způsob socialistické společnosti a srovnávaji kapitalistický a socialistický životní způsob. Socialistický životní způsob je definován jako "takový životní způsob, který je založen na ekonomických vztazích, kde svobodní a vysoce vzdělaní pracující pod vedením dělnické strany a její třídy uvědoměle budují svi̊j život a socialistické společenské vztahy" (str. 66). Obsah a charakter socialistíckého životního způsobu je určován socialistickým výrobním způsobem a třídním charakterem socialistické společnosti. Autoři ukazují, že jen $\mathrm{v}$ podmínkách socialismu je možná opravdová demokracie, demokracie proniknutá humanismem a pocitem odpovědnosti za socialistickou společnost. Jako nejdůležitější charakteristický rys socialistického životního zpuisobu je označován patriotismus a internacionalismus. Zdůrazñují se sociální garance, vědomí „bezpeči, které dovoluje jít s pocitem jistoty vstříc zítřkům" (str. 338 n.).

Autoři analyzují pojmy mravnost, morálka a jejich vztah ke společenskému vědomí. Zdůrazňují, že mravnost nelze pokládat jen za sféru společenského vědomí, že rozhodující význam má přitom charakter světového názoru, pomocí něhož se vyjadřují jistá přesvědčení. Akcentují nutnost rozšírit mravní přesvědčení dělnické tř̀idy na všechny třídy a vrstvy $v$ období výstavby socialismu a preměnit je $\mathrm{v}$ morálku celé společnosti. Z knihy vyplývají charakteristiky morálky různých sociálních vrstev socialistické společnosti, i když lze $\mathrm{z}$ textu vyvodit, že morálka $\mathrm{u}$ všech těchto vrstev je v podstatě shodná, nebot je podmínèna socialistickými společenskými vztahy.

Podrobně se analyzuje vztah kolektivu a osobnosti, poukazuje se na to, jak socialistický životní způsob utváří morální požadavky a vztahy lidí, zřetelně se určuje dialektika vzájemného působení osobních a společenských zájmů a uplatñuje se názor, že $v$ připadě nutnosti je nezbytné podřídit osobní zájmy zájmům celospolečenským.

Mnoho pozornosti se věnuje problému práce $v$ socialistické společnosti jako základu socialistického životního způsobu a morálky. Pro socialistický životní způsob jsou charakteristické vysoké mravní principy. Morálka a životní způsob za socialismu tvoři jistou jednotu. Tuto skutečnost autoři přesvědčivě ukazují na konkrétním procesu utváření nového člověka v NDR, vymezují jednotlivé etapy formování socialistické morálky v NDR. Začátek tohoto procesu spatřují $\mathrm{v}$ osvobození zemé od fašismu, kdy se vytvořily príiznivé podmínky pro rozvoj antifašistických demokratických sil, jejichž úkolem bylo „překonat do té doby vládnoucí imperialistické mravní normy a hodnoty a nahradit je novými normami a hodnotami, aby byl vytvořen životní způsob odpovídající lidské hodnotě “ (str. 104). Významnou úlohu $\checkmark$ tom sehrála komunistická strana, která se zaměrila zejména na formování dělnické morálky. Autoři připomínají, že V. sjezd komunistické strany $\mathrm{v}$ roce 1958 konstatoval vítězství dělnické morálky $\mathrm{v}$ širokých vrstvách obyvatelstva a vytyčil úkol formovat socialistickou morálku.

Objektivní předpoklady pro rozvíjení socialistického životního způsobu a morálky vytvářejí socialistické ekonomické a politické vztahy. Jejich struktura je taková, pripomínají autoři, že přispívají $\mathbf{k}$ identitě osobních a společenských zájmů. Tuto identitu však nelze chápat jako "mrtvou" totožnost, kde absentují jakékoli rozpory. a konflikty. Autoři správně připomínaji. že nidentita osobních zájmů a potřeb společenského vývoje jest dynamický proces, v němž neustále vznikají nové potřeby: nové zájmy a nové rozpory" (str. 178). Zamýšlejí se nad těmito rozpory a kcnstatují, že často mají objektivní charakter, když osobnost nebo jednotlivý kolektiv nesıači tempu sociálního vývoje a $s$ menšı efektivitou využivá obrovských možností socialistického zřizení. Nelze také nepřihližet ke konfliktům, jejichž povaha je 
určována csobními vlastnostmi lidí (199 n.). Velká úloha při řešení konfliktních situací, při úsili sladit společenské zájmy se zájmy osobními je přisuzována morálce. Proto je třeba se zabývat praktickým charakterem morálky.

Zvláštní kapitola je věnována problematice mládeže, otázkám jejího mravního vědomí. Zároveñ se autoři snaži vymezit rozdíly mezi chováním mládeže $\mathrm{v}$ kapitalistických a socialistických zemích. Akcentuji zde zejména skutečnost, že $\mathrm{v}$ socialistické společnosti má mládež všechny nezbytné podmínky $\mathbf{k}$ všestrannému rozvoji, $\checkmark$ souvislosti s nímž se formuje její mravní vědomí. Ovšem i zde, jak se $v$ monografii zdůrazñuje, existují určité disproporce, těžkosti a rozpory, na které autoři upozorn̆uji $\mathrm{v}$ souvislosti $s$ vnitřní logikou rozvíjeni osobnosti, s úlohou a významem různých věkových období.

V práci je věnována velká pozornost zkoumání těch ekonomických, politických a ideologických momentů, které podstatnè ovlivňuji morální profil člověka $v$ rozvinuté socialistické společnosti. Poukazuje se na zvláštní význam psychologického klimatu socialistické společnosti, které poskytuje každému člověku pocit sociálního bezpečí a které může vzniknout jen za socialismu, kde, jak autor̆i zdůrazñují, dèlnická třída má politickou moc a kde se uskutečňuje důsledná politika míru a politika, jež zajištuje právo na práci.

Charakteristiku životního způsobu a morálky za socialismu doplňuje zkoumání problémů rodiny, manželství, využití volného času a utváření estetických potřeb. V publikaci se uvádí bohatý faktický materiál, který názornè ukazuje a potvrzuje úspěchy NDR při vytváření rozvinuté socialistické společnosti a při formování nového socialistického člověka.

Celá kniha je prostoupena nekompromisnim bojem proti buržoazním teoriím zabý vajicím se životním způsobem a morálkou.

Kniha Životní způsob a morálka za socialismu zaujímá významné místo mezi publikacemi s podobnou tematikou, jichž se $\mathrm{v}$ poslední době objevilo mnoho ia knižním trhu. Je to tematika aktuální, a proto lze kladnè hodnotit snahu německých sociologů vymezit pojem životní způsob, specifikovat životní způsob za socialismu a určit jeho vztah $\mathrm{k}$ morálce, nebot, ve vědecké literatuře se velmi často setkáváme s pojmem "socialistický životní způsob“. Jeho obsah se však ne vždy přesně vymezuje, pojem zůstává nevyjasněný, mlhavý. Recenzovaná kniha vypln̆uje tuto mezeru, což je třeba hodnotit velmi pozitivně.

Při všech přednostech má však uvedená práce i některé nedostatky, na něž rovněž chceme upozornit. Je nutno konstatovat, že zatímco pojem životní způsob je analyzován velmi obšírně, zůstává problém morálky víceméně okrajovou záležitostí, je vyložen méně důkladně. Většinou se morálka chápe jen jako hodnocení životního způsobu za socialismu, ztrácí se specifičnost a jistá samostatnost, funkce morálky v životě socialistické společnosti. Analýza sociálních funkcí morálky by si podle našeho názoru zasluhovala větší pozornost, než jakou jí věnovali autoři recenzované knihy. Vědecká hodnota této práce je však nesporná a sborník jisté zaujme všechny, kteři se zabývají problé. my životního zpusobu a morálky v období vvyspělé socialistické společnosti.

Milena Manová

\section{Valentina Nikolajevna Pimenova: „Svobod-} noje vremja v socialističeskom obščestve" Izdatelstvo "Nauka“, Moskva 1974, (str. 311).Akademija nauk SSSR - Institut filozofii.

$\checkmark$ posledních letech se stal volný čas $\mathrm{v}$ Sovětském svazu mimořádně aktuálním problémem. Zkrácení délky pracovní doby ze sedmi na šest hodin $\mathrm{v}$ oblasti se škodlivými pracovnimi podmínkami a prechod na pětidenní pracovní týden se dvěma. volnými dny - to vše znamená zvětšení volného času. Kvantitativní růst volného času a nutnost výchovy nového člověka postavily před společnost úkol racionálnè využívat volný čas, tj. promýšlet takovou 